\title{
Actinomyces europaeus sp. nov., Isolated from Human Clinical Specimens
}

\author{
GUIDO FUNKE, ${ }^{1 *}$ NEREA ALVAREZ,${ }^{2}$ CRISTINA PASCUAL, ${ }^{2}$ ENEVOLD FALSEN, ${ }^{3}$ EVA AKERVALL, ${ }^{3}$ \\ LUC SABBE, ${ }^{4}$ LEO SCHOULS, ${ }^{5}$ NORBERT WEISS, ${ }^{6}$ AND MATTHEW D. COLLINS ${ }^{2}$ \\ Department of Medical Microbiology, University of Zürich, CH-8028 Zürich, Switzerland ${ }^{\text {; Department of }}$ \\ Microbiology, BBSRC Institute of Food Research, Reading Laboratory, Reading RG6 6BZ, United \\ Kingdom ${ }^{2}$; Culture Collection, Department of Clinical Bacteriology, University of Göteborg, \\ S-41346 Göteborg, Sweden"; Stichting Streeklaboratorium "Zeeland," NL-4460 AA Goes, ${ }^{4}$ \\ and National Institute of Public Health and Environmental Protection, NL-3720 \\ $B A$ Bilthoven, ${ }^{5}$ The Netherlands; and German Collection of Microorganisms \\ and Cell Cultures, D-38124 Braunschweig, Germany ${ }^{6}$
}

Ten strains of a hitherto undescribed catalase-negative, facultatively anaerobic, coryneform bacterium were isolated or collected by workers at three European clinical bacteriology laboratories or reference centers. These strains were isolated from humans, and most came from abscess material. Biochemical and chemotaxonomic characterization revealed that the strains belonged to the genus Actinomyces. The phenotypic features of the 10 strains were incompatible with the descriptions of the previously established Actinomyces species. A comparative 16S rRNA gene sequence analysis demonstrated that the previously undescribed strains constitute a new line in the genus Actinomyces. The name Actinomyces europaeus sp. nov. is proposed for these clinical isolates. The type strain is CCUG 32789A.

In the $1990 \mathrm{~s}$, there has been increasing recognition of the importance of coryneform bacteria (i.e., aerobic, asporogenous, irregular, non-partially acid-fast, gram-positive rods) as opportunistic human pathogens (8). As a result of increased medical interest in such organisms, combined with intensified taxonomic investigations, a number of new coryneform and related high- $\mathrm{G}+\mathrm{C}$-content bacteria have been described in recent years (8). The recognition of new coryneform pathogens in laboratories is complicated by the absence of reliable commercial identification systems with in-depth databases and the heterogeneity of the organisms encountered. Recent studies have shown, however, that the use of phenotypic approaches (biochemical profiles, lipids, cell walls) and molecular taxonomic approaches (e.g., 16S rRNA sequencing) in concert (polyphasic taxonomy) provides not only a powerful means for recognizing and delineating such organisms, but also the foundation for developing improved identification schemes. In this article we report the use of a polyphasic approach to characterize a group of 10 catalase-negative, facultatively anaerobic, coryneform bacterial strains obtained from human clinical specimens, which could not be assigned to any previously established taxon. Based on the results of the present study, a new species, Actinomyces europaeus, is proposed.

\section{MATERIALS AND METHODS}

Bacterial strains. The origins of the strains studied and their clinical sources are given in Table 1. Four strains were isolated by workers at the Department of Medical Microbiology, University of Zürich, Zürich, Switzerland, and three strains were isolated by workers at the Stichting Streeklaboratorium, Goes, The Netherlands, by standard methods (5). The three remaining isolates were referred to the Culture Collection of the University of Göteborg, Göteborg, Sweden.

Morphological and biochemical characteristics. The strains were grown aerobically at $37^{\circ} \mathrm{C}$ in a $5 \% \mathrm{CO}_{2}$-enriched atmosphere on Columbia agar (Difco Laboratories, Detroit, Mich.) supplemented with 5\% sheep blood. The same

* Corresponding author. Mailing address: Department of Medical Microbiology, University of Zürich, Gloriastrasse 32, CH-8028 Zürich, Switzerland. Phone: 41-1-257-2700. Fax: 41-1-252-8107. E-mail: funke @immv.unizh.ch. medium was used to assess growth in a strictly anaerobic atmosphere $\left(10 \% \mathrm{H}_{2}\right.$, $10 \% \mathrm{CO}_{2}, 80 \% \mathrm{~N}_{2}$ ). The methods used to determine the biochemical profiles of the bacteria have been described in detail previously (5). Using the commercial API Coryne system (bioMérieux, Marcy l'Etoile, France), we read enzymatic reactions after $24 \mathrm{~h}$ of incubation at $37^{\circ} \mathrm{C}$, whereas fermentation reactions were observed after $72 \mathrm{~h}$ of incubation. Additional enzymatic reactions were studied by using the API ZYM system (bioMérieux). The API 50CH system (carbohydrate fermentations) was used in conjunction with 50CHE medium (both obtained from bioMérieux), and reactions were read after $120 \mathrm{~h}$ of incubation at $37^{\circ} \mathrm{C}$.

Antimicrobial agent susceptibility tests. MICs of 24 antimicrobial agents were determined by a microdilution method; 96 -well microtiter plates contained the antibiotics in lyophilized form with one starting concentration and 11 twofold dilutions (i.e., there were eight antimicrobial agents per plate) (Merlin Diagnostics, Bornheim-Hersel, Germany). A bacterial suspension (McFarland standard 05 ) was prepared in $0.9 \% \mathrm{NaCl}, 200 \mu \mathrm{l}$ of the suspension was transferred into 10 $\mathrm{ml}$ of $\mathrm{H}$-medium (Merlin), and $100 \mu \mathrm{l}$ of this preparation was added to each well of the microtiter plate. The plates were incubated in a $5 \% \mathrm{CO}_{2}$-enriched atmosphere at $35^{\circ} \mathrm{C}$. Bacterial growth was observed after $48 \mathrm{~h}$ by reading the microtiter plates with an automated Multiskan MS reader (Labsystems Oy, Helsinki, Finland) at a wavelength of $620 \mathrm{~nm}$. An emission adsorbance value of $\geq 0.130$ indicated growth. All of the plates were also examined by eye for bacterial growth, but no discrepancies were observed.

$\mathrm{MIC}_{50}$ was the MIC of an antimicrobial agent at which $50 \%$ of the isolates were inhibited, and $\mathrm{MIC}_{90}$ was the MIC at which $90 \%$ of the isolates were inhibited.

Gas-liquid chromatography. Cells were grown under anaerobic conditions in PRAS chopped meat carbohydrate broth (9) for $48 \mathrm{~h}$ at $37^{\circ} \mathrm{C}$ to determine the end products of fermentation. The detection method used has been described previously (5). Cellular fatty acid patterns were generated by using the Sherlock Microbial Identification System (Microbial ID, Inc., Newark, Del.) (21).

Cell wall analysis. The peptidoglycan structure was determined by the method of Schleifer and Kandler (18), except that ascending thin-layer chromatography on cellulose sheets (Merck, Darmstadt, Germany) was used.

PAGE of whole-cell proteins. Most strains were grown on horse blood agar (Columbia base) at $37^{\circ} \mathrm{C}$ in the presence of $5 \% \mathrm{CO}_{2}$; the only exception was Actinomyces israelii CCUG $18307^{\mathrm{T}}$, which was grown under anaerobic conditions. Polyacrylamide gel electrophoresis (PAGE) of whole-cell proteins was performed as described previously (15). For densitometric analysis, normalization, and interpretation of protein patterns, the Gelcompar 3.1 software package (Applied Maths, Kortrijk, Belgium) was used. Levels of correlation are presented below as percentages of similarity.

DNA base composition. DNAs were prepared and $\mathrm{G}+\mathrm{C}$ contents were determined as described previously (6).

Determination of $16 S$ rRNA gene sequences and phylogenetic analyses. A large fragment of the $16 \mathrm{~S}$ rRNA gene was amplified by PCR by using universal primers pA (5'-AGAGTTTGATCCTGGCTCAG; positions 8 to 27 [Escherichia coli numbering]) and $\mathrm{pH}^{*}$ (5'-AAGGAGGTGATCCAGCCGCA; positions 
TABLE 1. Origins of the strains studied

\begin{tabular}{|c|c|c|c|c|}
\hline \multirow[b]{2}{*}{ Strain $^{a}$} & \multirow{2}{*}{$\begin{array}{l}\text { Year iso- } \\
\text { lated }\end{array}$} & \multicolumn{2}{|c|}{ Patient } & \multirow[b]{2}{*}{ Source } \\
\hline & & $\operatorname{Sex}^{b}$ & $\begin{array}{l}\text { Age } \\
\text { (yr) }\end{array}$ & \\
\hline DMMZ 747 (= DSM 11076) & 1993 & $\mathrm{~F}$ & 50 & Abscess \\
\hline $\begin{array}{l}\text { DMMZ } 1113 \text { (= DSM } 11077 \\
\quad=\text { CCUG 35467) }\end{array}$ & 1994 & $\mathrm{~F}$ & 54 & Breast abscess \\
\hline $\begin{array}{l}\text { DMMZ } 1284(=\text { DSM } 11078 \\
\quad=\text { CCUG } 35470)\end{array}$ & 1995 & M & 27 & Suprapubic abscess \\
\hline DMMZ 2233 & 1996 & $\mathrm{M}$ & 35 & Perianal abscess \\
\hline CCUG $32789 A^{\mathrm{T}}$ & 1994 & M & 63 & Femur tissue \\
\hline CCUG 33355 & 1994 & $\mathrm{NK}^{c}$ & 65 & Abscess \\
\hline CCUG $34687(=$ CDC F7662) & 1986 & $\mathrm{~F}$ & NK & Labial abscess \\
\hline LMG 16599 (= CCUG 35554) & 1986 & $\mathrm{M}$ & 57 & Perianal abscess \\
\hline LMG $16600(=$ CCUG 35548) & 1987 & $\mathbf{M}$ & 64 & Decubital ulcer \\
\hline LMG 16601 (= CCUG 35549) & 1988 & $\mathrm{~F}$ & 62 & Atherom cyst \\
\hline
\end{tabular}

${ }^{a}$ DMMZ, Department of Medical Microbiology, University of Zürich; DSM, German Collection of Microorganisms and Cell Cultures; CCUG, Culture Collection, Department of Clinical Bacteriology, University of Göteborg; CDC, Centers for Disease Control and Prevention, Atlanta, Ga.; LMG, Microbiology Laboratory, University of Ghent.

${ }^{b} \mathrm{~F}$, female; $\mathrm{M}$, male.

${ }^{c} \mathrm{NK}$, not known.

1541 to 1522 ) as previously described (11). The PCR products were purified by using a Prep-A-Gene kit (Bio-Rad, Hercules, Calif.) according to the manufacturer's instructions and were sequenced by using a Taq DyeDeoxy terminator cycle sequencing kit (Applied Biosystems, Inc., Foster City, Calif.) and a model 373A automatic sequencer (Applied Biosystems, Inc.). The sequences determined and the sequences of other high-G+C-content actinomycetes (obtained from the EMBL Data Library) were aligned by using the program PILEUP (2), and the alignment was corrected manually. Distance matrices were produced by using the DNADIST program of the PHYLIP package (3). Unrooted phylogenetic trees were constructed with the algorithm of Fitch and Margoliash (4) and by using the neighbor-joining method of Saitou and Nei (16). The statistical significance of the groups obtained was assessed by bootstrapping ( 500 replicates) by using the programs SEQBOOT, DNADIST, NEIGHBOR, and CONSENSE (3).

Nucleotide sequence accession number. The $16 \mathrm{~S}$ rRNA gene sequence of strain CCUG $32789 \mathrm{~A}^{\mathrm{T}}$ which we determined has been deposited in the EMBL Data Library under accession no. Y08828.

\section{RESULTS AND DISCUSSION}

Seven of the 10 clinical strains were isolated from human abscesses (Table 1). In the majority of the cases the coryneform organism was the only aerobically growing bacterium, but on anaerobically incubated culture plates a mixed anaerobic flora (i.e., at least three morphologically different anaerobes) was detected. Therefore, the etiologic role of the unidentified coryneform bacterium as a pathogen remained unclear. Similar clinical sources have been reported for Arcanobacterium bernardiae (7), as well as for Actinomyces radingae and Actinomyces turicensis strains $(13,22,23)$.

Colonies of the strains were translucent, grayish, and less than $0.5 \mathrm{~mm}$ in diameter after $48 \mathrm{~h}$ of incubation in a $5 \%$ $\mathrm{CO}_{2}$-enriched atmosphere at $37^{\circ} \mathrm{C}$. The growth rate under strictly anaerobic conditions was similar to the growth rate described above. Some strains exhibited very slight beta-hemolysis on sheep blood agar plates. Gram staining of the organisms revealed relatively short gram-positive rods with irregular morphology and no filament formation.

According to the general typing scheme for coryneform bacteria encountered in clinical specimens outlined by von Graevenitz and Funke (20), we observed the following biochemical characteristics: catalase-negative, fermentative, nonmotile rods; negative for nitrate reduction and urea hydrolysis; variable for hydrolysis of esculin; positive for fermentation of glucose and maltose but not for fermentation of mannitol and xylose; variable for fermentation of sucrose; and negative for the CAMP reaction (Table 2). All of the strains produced large amounts of succinic acid as the end product of glucose fermentation. The strains were, therefore, considered members of an Actinomyces species. The biochemical profile study was extended by using the API Coryne system. The results of the initial biochemical screening reactions were confirmed, and the organisms were tentatively designated Enevold Falsen (EF) group 43 bacteria, Arcanobacterium bernardiae-like bacteria, or CDC coryneform group E-like bacteria (10) by the different collaborators who participated in this joint project as the biochemical profile was incompatible with the profiles of previ-

TABLE 2. Characteristics that differentiate Actinomyces europaeus from other human-derived, aerobically growing Actinomyces and Arcanobacterium species ${ }^{a}$

\begin{tabular}{|c|c|c|c|c|c|c|c|c|c|c|c|c|c|c|c|}
\hline Species & 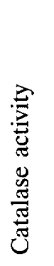 & 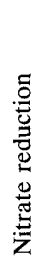 & 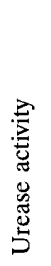 & 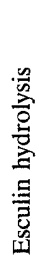 & $\begin{array}{l}\ddot{8} \\
\stackrel{8}{0} \\
\end{array}$ & $\frac{\mathscr{J}}{\stackrel{\Xi}{g}}$ & 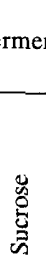 & $\begin{array}{l}\bar{g} \\
\stackrel{\Xi}{\Xi} \\
\stackrel{\Xi}{\Sigma}\end{array}$ & $\frac{\ddot{y}}{\grave{x}}$ & $\begin{array}{l}\text { D: } \\
\stackrel{0}{0} \\
\stackrel{0}{0} \\
\stackrel{2}{0}\end{array}$ & 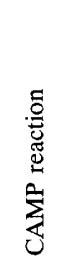 & 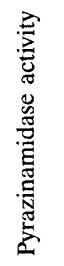 & 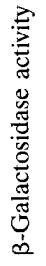 & 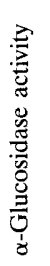 & 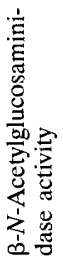 \\
\hline Actinomyces europaeus & $-b$ & - & - & $\mathrm{V}$ & + & + & $\mathrm{V}$ & - & - & $\mathrm{V}$ & - & - & + & + & - \\
\hline Arcanobacterium bernardiae & - & - & - & - & + & + & - & - & - & + & - & + & - & + & - \\
\hline Arcanobacterium haemolyticum ${ }^{c}$ & - & - & - & - & + & + & $\mathrm{V}$ & - & - & - & REV & + & + & + & + \\
\hline Actinomyces naeslundii & V & $\mathrm{V}$ & + & + & + & + & + & - & $\mathrm{V}$ & $\mathrm{V}$ & - & ND & $\mathrm{V}$ & $\mathrm{V}$ & - \\
\hline Actinomyces neuii & + & $\mathrm{V}$ & - & - & + & + & + & + & + & - & + & + & + & + & - \\
\hline Actinomyces odontolyticus ${ }^{d}$ & - & + & - & $\mathrm{V}$ & + & $\mathrm{V}$ & + & - & $\mathrm{V}$ & $\mathrm{V}$ & - & ND & - & - & - \\
\hline Arcanobacterium pyogenes ${ }^{c}$ & - & - & - & $\mathrm{V}$ & + & V & $\mathrm{V}$ & $\mathrm{V}$ & + & + & - & - & + & + & - \\
\hline Actinomyces radingae & - & - & - & + & + & + & + & $\mathrm{V}$ & + & - & - & + & + & + & + \\
\hline Actinomyces turicensis & - & - & - & - & + & + & + & $\mathrm{V}$ & + & - & - & - & - & + & - \\
\hline Actinomyces viscosus & + & + & V & $\mathrm{V}$ & + & + & + & - & $\mathrm{V}$ & $\mathrm{V}$ & - & ND & $\mathrm{V}$ & $\mathrm{V}$ & - \\
\hline
\end{tabular}

${ }^{a}$ Data from references $5,7,8,10,12,17$, and 23

${ }^{b}$ - , negative; + , positive; $\mathrm{V}$, variable; REV, reverse CAMP reaction; ND, no data available.

c This organism exhibits beta-hemolysis on sheep blood agar.

${ }^{d}$ A brown-red pigment is formed in older colonies. 
ously established Actinomyces species (Table 2). The strains were initially designated Arcanobacterium bernardiae-like because they fermented maltose more rapidly than they fermented glucose, like Arcanobacterium bernardiae (8), and because their biochemical profile was similar to that of Arcanobacterium bernardiae (7), which ferments glycogen but not sucrose and which does not hydrolyze esculin (Table 2). The unknown coryneform bacteria also phenotypically resembled CDC coryneform group E bacteria $(10,13)$ (i.e., Actinomyces radingae and Actinomyces turicensis [23]) except that they did not ferment xylose (Table 2). If hydrolysis of esculin was positive, it was delayed (occurring only after 72 to $96 \mathrm{~h}$ of incubation), as was hydrolysis of gelatin (as determined by the API Coryne system), which was positive only after 5 days of incubation at $37^{\circ} \mathrm{C}$.

The MICs of all of the penicillins tested against the 10 new coryneform strains were very low. For amoxicillin the MIC range was $\leq 0.0625$ to $0.125 \mu \mathrm{g} / \mathrm{ml}$, the $\mathrm{MIC}_{50}$ was $\leq 0.0625$ $\mu \mathrm{g} / \mathrm{ml}$, and the $\mathrm{MIC}_{90}$ was $\leq 0.0625 \mu \mathrm{g} / \mathrm{ml}$; for oxacillin the MIC range was 0.25 to $1 \mu \mathrm{g} / \mathrm{ml}$, the $\mathrm{MIC}_{50}$ was $0.5 \mu \mathrm{g} / \mathrm{ml}$, and the $\mathrm{MIC}_{90}$ was $1 \mu \mathrm{g} / \mathrm{ml}$; for penicillin $\mathrm{G}$ the $\mathrm{MIC}$ range was $\leq 0.016$ to $0.125 \mu \mathrm{g} / \mathrm{ml}$, the $\mathrm{MIC}_{50}$ was $0.032 \mu \mathrm{g} / \mathrm{ml}$, and the $\mathrm{MIC}_{90}$ was $0.0625 \mu \mathrm{g} / \mathrm{ml}$; and for piperacillin the MIC range was $\leq 0.125$ to $0.5 \mu \mathrm{g} / \mathrm{ml}$, the $\mathrm{MIC}_{50}$ was $0.25 \mu \mathrm{g} / \mathrm{ml}$, and the $\mathrm{MIC}_{90}$ was $0.25 \mu \mathrm{g} / \mathrm{ml}$. The MICs of most cephalosporins were also very low. For cefazolin the MIC range was $\leq 0.125$ to 0.5 $\mu \mathrm{g} / \mathrm{ml}$, the $\mathrm{MIC}_{50}$ was $\leq 0.125 \mu \mathrm{g} / \mathrm{ml}$, and the $\mathrm{MIC}_{90}$ was 0.25 $\mu \mathrm{g} / \mathrm{ml}$; for cefoxitin the MIC range was 0.125 to $0.5 \mu \mathrm{g} / \mathrm{ml}$, the $\mathrm{MIC}_{50}$ was $0.125 \mu \mathrm{g} / \mathrm{ml}$, and the $\mathrm{MIC}_{90}$ was $0.25 \mu \mathrm{g} / \mathrm{ml}$; and for ceftriaxone the MIC range was $\leq 0.032$ to $0.25 \mu \mathrm{g} / \mathrm{ml}$, the $\mathrm{MIC}_{50}$ was $0.0625 \mu \mathrm{g} / \mathrm{ml}$, and the $\mathrm{MIC}_{90}$ was $0.25 \mu \mathrm{g} / \mathrm{ml}$. However, the MICs of some cephalosporins were significantly higher. For cefetamet the MIC range was 8 to $>64 \mu \mathrm{g} / \mathrm{ml}$, the $\mathrm{MIC}_{50}$ was $32 \mu \mathrm{g} / \mathrm{ml}$, and the $\mathrm{MIC}_{90}$ was $>64 \mu \mathrm{g} / \mathrm{ml}$; and for cefibuten the MIC range was 4 to $16 \mu \mathrm{g} / \mathrm{ml}$, the $\mathrm{MIC}_{50}$ was 8 $\mu \mathrm{g} / \mathrm{ml}$, and the $\mathrm{MIC}_{90}$ was $8 \mu \mathrm{g} / \mathrm{ml}$. For the carbapenem imipenem the MIC range was 0.125 to $0.25 \mu \mathrm{g} / \mathrm{ml}$, the $\mathrm{MIC}_{50}$ was $0.125 \mu \mathrm{g} / \mathrm{ml}$, and the $\mathrm{MIC}_{90}$ was $0.25 \mu \mathrm{g} / \mathrm{ml}$; and for the carbapenem meropenem the MIC range was 0.0625 to $0.125 \mu \mathrm{g} /$ $\mathrm{ml}$, the $\mathrm{MIC}_{50}$ was $0.0625 \mu \mathrm{g} / \mathrm{ml}$, and the $\mathrm{MIC}_{90}$ was 0.125 $\mu \mathrm{g} / \mathrm{ml}$. For the macrolide erythromycin the MIC range was $\leq 0.032$ to $4 \mu \mathrm{g} / \mathrm{ml}$, the $\mathrm{MIC}_{50}$ was $\leq 0.032 \mu \mathrm{g} / \mathrm{ml}$, and the $\mathrm{MIC}_{90}$ was $\leq 0.032 \mu \mathrm{g} / \mathrm{ml}$ (only strain DMMZ 1284 was resistant); and for the macrolide clarithromycin the MIC range for all of the strains was $\leq 0.032$ to $2 \mu \mathrm{g} / \mathrm{ml}$, the $\mathrm{MIC}_{50}$ was $\leq 0.032$ $\mu \mathrm{g} / \mathrm{ml}$, and the $\mathrm{MIC}_{90}$ was $\leq 0.032 \mu \mathrm{g} / \mathrm{ml}$. For the tetracycline doxycycline the MIC range was 0.25 to $16 \mu \mathrm{g} / \mathrm{ml}$, the $\mathrm{MIC}_{50}$ was $0.5 \mu \mathrm{g} / \mathrm{ml}$, and the MIC Mo $_{\text {w }}$ was $\mu \mathrm{g} / \mathrm{ml}$ (only strain LMG 16600 was resistant); and for tetracycline the MIC range for all of the strains was 0.5 to $32 \mu \mathrm{g} / \mathrm{ml}$, the $\mathrm{MIC}_{50}$ was $1 \mu \mathrm{g} / \mathrm{ml}$, and the $\mathrm{MIC}_{\varphi_{0}}$ was $2 \mu \mathrm{g} / \mathrm{ml}$. For the glycopeptide teicoplanin the MIC range was $\leq 0.0625$ to $0.25 \mu \mathrm{g} / \mathrm{ml}$, the $\mathrm{MIC}_{50}$ was 0.125 $\mu \mathrm{g} / \mathrm{ml}$, and the $\mathrm{MIC}_{90}$ was $0.25 \mu \mathrm{g} / \mathrm{ml}$; and for the glycopeptide vancomycin the MIC range was 0.5 to $1 \mu \mathrm{g} / \mathrm{ml}$, the $\mathrm{MIC}_{50}$ was $1 \mu \mathrm{g} / \mathrm{ml}$, and the $\mathrm{MIC}_{90}$ was $1 \mu \mathrm{g} / \mathrm{ml}$. For chloramphenicol the MIC range was 0.25 to $1 \mu \mathrm{g} / \mathrm{ml}$, the $\mathrm{MIC}_{50}$ was $0.5 \mu \mathrm{g} / \mathrm{ml}$, and the $\mathrm{MIC}_{90}$ was $1 \mu \mathrm{g} / \mathrm{ml}$; for clindamycin the MIC range for all of the strains tested was $\leq 0.0156$ to $>32 \mu \mathrm{g} / \mathrm{ml}$, the $\mathrm{MIC}_{50}$ was $0.032 \mu \mathrm{g} / \mathrm{ml}$, and the $\mathrm{MIC}_{90}$ was $0.032 \mu \mathrm{g} / \mathrm{ml}$ (only strain DMMZ 1284 was resistant); and for rifampin the MIC range was $\leq 0.016$ to $0.032 \mu \mathrm{g} / \mathrm{ml}$, the $\mathrm{MIC}_{50}$ was $\leq 0.016 \mu \mathrm{g} / \mathrm{ml}$, and the $\mathrm{MIC}_{90}$ was $\leq 0.016 \mu \mathrm{g} / \mathrm{ml}$. For the aminoglycoside amikacin the MIC range was 4 to $16 \mu \mathrm{g} / \mathrm{ml}$, the $\mathrm{MIC}_{50}$ was $8 \mu \mathrm{g} / \mathrm{ml}$, and the $\mathrm{MIC}_{90}$ was $16 \mu \mathrm{g} / \mathrm{ml}$; and for the aminoglycoside tobramycin the MIC range was 1 to $4 \mu \mathrm{g} / \mathrm{ml}$, the $\mathrm{MIC}_{50}$ was 2 $\mu \mathrm{g} / \mathrm{ml}$, and the $\mathrm{MIC}_{90}$ was $4 \mu \mathrm{g} / \mathrm{ml}$. Two quinolones were also tested. For ciprofloxacin the MIC range was 0.5 to $1 \mu \mathrm{g} / \mathrm{ml}$, the $\mathrm{MIC}_{50}$ was $1 \mu \mathrm{g} / \mathrm{ml}$, and the $\mathrm{MIC}_{90}$ was $1 \mu \mathrm{g} / \mathrm{ml}$; and for ofloxacin the MIC range was 2 to $4 \mu \mathrm{g} / \mathrm{ml}$, the $\mathrm{MIC}_{50}$ was 2 $\mu \mathrm{g} / \mathrm{ml}$, and the $\mathrm{MIC}_{90}$ was $4 \mu \mathrm{g} / \mathrm{ml}$. The susceptibility pattern described above is consistent with the susceptibility patterns obtained for almost all previously described Actinomyces species (17)

An analysis of the cellular fatty acids (CFAs) revealed that $\mathrm{C}_{16: 0}(33 \% \pm 2 \%$ of the total CFAs [mean \pm standard deviation]), $\mathrm{C}_{18: 1 \omega 9}(22 \% \pm 3 \%)$, and $\mathrm{C}_{18: 0}(20 \% \pm 3 \%)$ were the main CFAs. Significantly, $\mathrm{C}_{10: 0}(1 \% \pm 1 \%), \mathrm{C}_{12: 0}(1 \% \pm 1 \%)$, and $\mathrm{C}_{14: 0}(3 \% \pm 1 \%)$ were also detected; these CFAs are indicators that the strains should be assigned to the genus Actinomyces or the genus Arcanobacterium (1). The CFA profiles of the new coryneform bacterium both qualitatively and quantitatively matched the CFA profiles of CDC coryneform group $\mathrm{E}$ strains as reported by Bernard et al. (1). An analysis of partial peptidoglycan hydrolysates revealed that the murein type was the L-lysine-L-lysine-D-glutamic acid type (type A $5 \alpha$ ), as has been described for Actinomyces neuil and Arcanobacterium haemolyticum (21a). The $\mathrm{G}+\mathrm{C}$ contents of four representative strains of the previously undescribed coryneform bacterium were found to be 61 to $63 \mathrm{~mol} \%$ values which are within the range of values obtained for members of the genus Actinomyces (17).

The whole-cell protein profiles of 7 of the 10 strains listed in Table 1 were examined by sodium dodecyl sulfate-PAGE. A dendrogram derived from a numerical analysis of the protein profiles is shown in Fig. 1. All seven strains grouped together and formed a distinct branch with a within-group correlation level of more than $80 \%$. This indicated that the strains examined represent a homogeneous group and that they are distinct from all other Actinomyces and Arcanobacterium species examined.

To investigate the genetic relationships of the new coryneform bacterium, the genes encoding the $16 \mathrm{~S}$ rRNAs of six strains were amplified by PCR and subjected to a sequence analysis. The almost complete $16 \mathrm{~S}$ rRNA gene sequences of two strains (DMMZ 1113 and CCUG 32789A ${ }^{\mathrm{T}}$ ) were determined. Each sequence consisted of approximately 1,430 nucleotides, and only a single base difference was found between the two strains (level of sequence similarity, $>99.9 \%$ ). Comparative sequence searches of the EMBL and GenBank libraries by using the FASTA program (2) revealed that the newly determined sequences were most closely related to sequences of species belonging to the genus Actinomyces (data not shown). The sequence of strain CCUG $32789 \mathrm{~A}^{\mathrm{T}}$ was subjected to a pairwise analysis with the sequences of Actinomyces spp. and some close relatives, and derived evolutionary distances were used to determine phylogenetic relationships. A tree depicting the phylogenetic position of strain CCUG $32789 \mathrm{~A}^{\mathrm{T}}$ within the genus Actinomyces is shown in Fig. 2, and the levels of sequence similarity between the new Actinomyces species and other Actinomyces spp. are shown in Table 3. The new organism formed a relatively long line and did not exhibit close affinity with any previously recognized Actinomyces species. The sequence divergence values (Table 3 ), with the closest relative exhibiting $<92 \% 16 \mathrm{~S}$ rRNA gene homology, clearly demonstrated (19) that the new strain represents a hitherto unknown subline within the genus Actinomyces. To determine whether the sequences of strains CCUG $32789 \mathrm{~A}^{\mathrm{T}}$ and DMMZ 1113 were characteristic of the group of isolates, partial sequences of four other strains (DMMZ 747, DMMZ 1284, CCUG 33355, and CCUG 34687) were determined. Short fragments (approximately 700 bases; positions 40 to $760[$ E. coli numbering]) which included highly diagnostic regions V1 to V4 


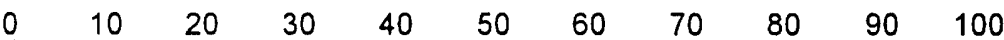

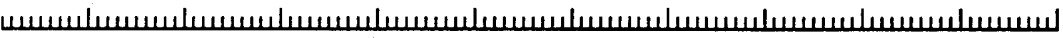

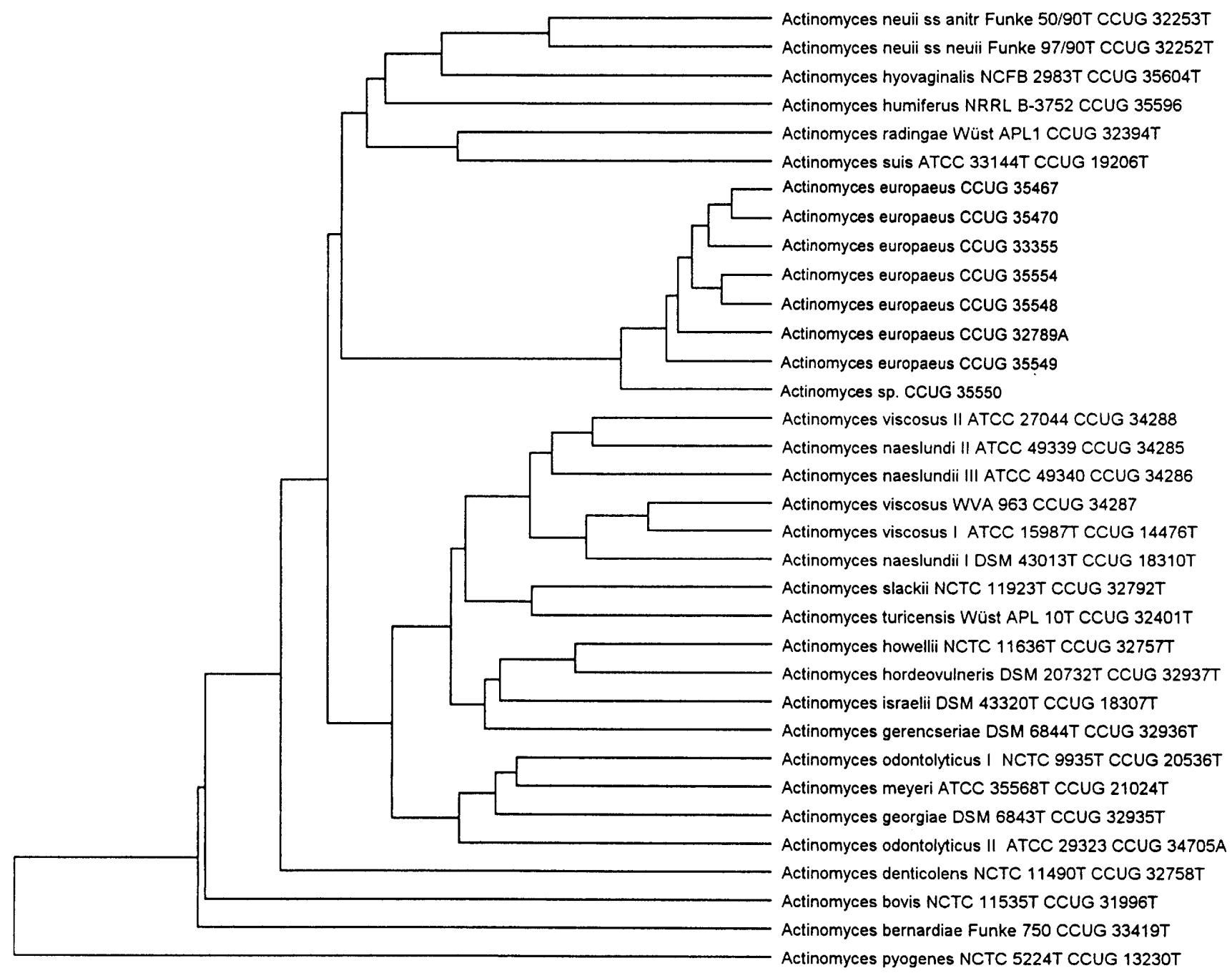

FIG. 1. Similarity dendrogram based on whole-cell protein patterns of Actinomyces europaeus and related species. Levels of correlation were expressed as percentages of similarity for convenience.

were sequenced, and the strains were found to be genealogically very homogeneous (zero to two differences were found).

The results of both phenotypic and phylogenetic studies demonstrate that the EF group 43 bacteria (Arcanobacterium bernardiae-like bacteria, CDC coryneform group E-like bacteria) described above constitute a new species. Phylogenetically, the new species forms a long isolated line within the genus Actinomyces. Pascual Ramos et al. (14) recently conducted a detailed comparative $16 \mathrm{~S}$ rRNA analysis of Actinomyces spp. and showed that the genus Actinomyces (as presently defined) is not monophyletic. Both sequence divergence and tree topology considerations indicate that the genus Actinomyces is in urgent need of taxonomic revision and should be subdivided into several genera (14). Assignment of the EF group 43 bacteria to the genus Actinomyces is the most appropriate assignment at present, although we recognize that in the future this assignment may require emendation as the taxonomy of the genus Actinomyces is revised. Based on the results of the present findings, we propose that the EF group 43 bacteria (Arcanobacterium bernardiae-like bacteria, CDC coryneform group E-like bacteria) described above should be classified in a new species of the genus Actinomyces, for which we propose the name Actinomyces europaeus.

Description of Actinomyces europaeus sp. nov. Actinomyces europaeus (eu.ro.pae'us. L. adj. europaeus, European, referring to the fact that six different European laboratories contributed to this study). The following description is based on the results of a study of 10 strains.

Cells are short (length, 0.5 to $1.5 \mu \mathrm{m}$ ) gram-positive rods that sometimes are arranged in clusters. Cells are nonmotile and do not form spores. Colonies are circular and smooth with a translucent grayish appearance and are not more than 0.5 $\mathrm{mm}$ in diameter after $48 \mathrm{~h}$ of incubation in a $5 \% \mathrm{CO}_{2}$-enriched atmosphere at $37^{\circ} \mathrm{C}$. Facultatively anaerobic. Catalase is not produced. Acid is produced from glucose, maltose, galactose, and D-fructose. Fermentation of sucrose, ribose, adonitol, Dmannose, $\alpha$-methyl-D-mannoside, $\alpha$-methyl-D-glucoside, melibiose, trehalose, melezitose, amidon, glycogen, and D-turanose is variable. Acid is not produced from mannitol, xylose, Larabinose, $\beta$-methyl-xyloside, rhamnose, dulcitol, sorbitol, 


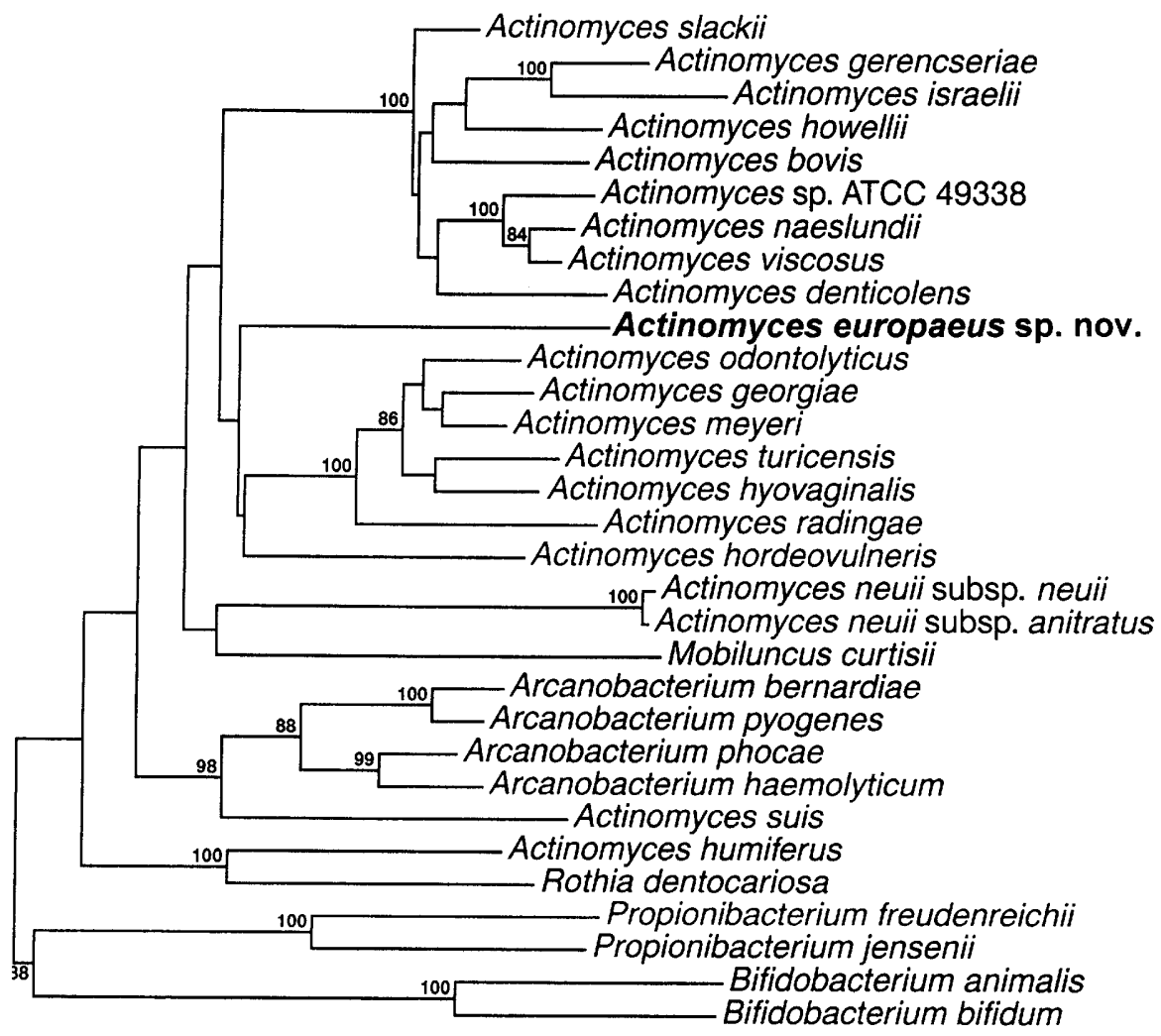

FIG. 2. Unrooted tree showing the phylogenetic relationships of Actinomyces europaeus, other members of the genus Actinomyces, and related taxa. The tree was constructed by using the neighbor-joining method and was based on a comparison of approximately 1,320 nucleotides. Bootstrap values, expressed as percentages of 500 replications, are given at the branch points.

TABLE 3. Levels of 16S rRNA gene sequence similarity between Actinomyces europaeus sp. nov. and related species

Species, subspecies, or strain
(EMBL no.)

\footnotetext{
${ }^{a}$ The numbers in parentheses are EMBL 16S rRNA nucleotide sequence
} accession numbers. amygdalin, arbutin, salicin, lactose, inulin, D-raffinose, $\beta$-gentiobiose, and 2-ketogluconate. Nitrate is not reduced to nitrite. Urea is not hydrolyzed, and esculin hydrolysis is variable. $\beta$-Galactosidase, $\alpha$-glucosidase, esterase, esterase-lipase, leucine arylamidase, valine arylamidase, and $\alpha$-galactosidase activities are present, whereas pyrazinamidase, pyrrolidonyl arylamidase, $\beta$-glucuronidase, $N$-acetyl-glucosaminidase, alkaline phosphatase, trypsin, chymotrypsin, $\beta$-glucosidase, and $\alpha$-mannosidase activities are not detected. Succinic acid is the main end product of fermentation. Palmitic and stearic acids are the main straight-chain cellular fatty acids, while oleic acid is the predominant unsaturated fatty acid. The interpeptide bridge in the peptidoglycan is L-lysine-L-lysine-D-glutamic acid (type A5 $\alpha$ ). The DNA base composition is 61 to $63 \mathrm{~mol} \% \mathrm{G}+\mathrm{C}$. Strains are isolated mainly from human abscesses. The habitat of the strains is unknown. Type strain CCUG 32789A has been deposited in Culture Collection of the University of Göteborg, Göteborg, Sweden. The type strain has the characteristics described above for the species. It does not hydrolyze esculin and does not ferment sucrose. The $\mathrm{G}+\mathrm{C}$ content of the type strain is $62 \mathrm{~mol} \%$.

\section{ACKNOWLEDGMENTS}

We thank A. von Graevenitz for a careful review of the manuscript. We thank B. Sjöden for excellent technical assistance.

This work was supported by grants BIO-CT93-0119, BIO-CT943098, and CHRX-CT93-0194 from the European Union and by a grant from the Jubiläumsspende der Universität Zürich. E.F. gratefully acknowledges the financial support of $\mathrm{H}$. Jungvid and $\mathrm{N}$. Strömberg.

\section{REFERENCES}

1. Bernard, K. A., M. Bellefeuille, and E. P. Ewan. 1991. Cellular fatty acid composition as an adjunct to the identification of asporogenous, aerobic 
gram-positive rods. J. Clin. Microbiol. 29:83-89.

2. Devereux, J., P. Haeberli, and O. Smithies. 1984. A comprehensive set of sequence analysis programs for the VAX. Nucleic Acids Res. 12:387-395.

3. Felsenstein, J. 1989. PHYLIP-phylogeny inference package (version 3.2). Cladistics 5:164-166.

4. Fitch, W. M., and E. Margoliash. 1967. Construction of phylogenetic trees: a method based on mutation distances as estimated from cytochrome $c$ sequences is of general applicability. Science 155:279-284.

5. Funke, G., G. Martinetti-Lucchini, G. E. Pfyffer, M. Marchiani, and A. von Graevenitz. 1993. Characteristics of CDC group 1 and group 1-like coryneform bacteria isolated from clinical specimens. J. Clin. Microbiol. 31:29072912.

6. Funke, G., C. Pascual Ramos, and M. D. Collins. 1995. Identification of some clinical strains of CDC coryneform group A-3 and group A-4 bacteria as Cellulomonas species and proposal of Cellulomonas hominis sp. nov. for some group A-3 strains. J. Clin. Microbiol. 33:2091-2097.

7. Funke, G., C. Pascual Ramos, J. Fernandez-Garayzabal, N. Weiss, and M. D. Collins. 1995. Description of human-derived Centers for Disease Control coryneform group 2 bacteria as Actinomyces bernardiae sp. nov. Int. J. Syst. Bacteriol. 45:57-60.

8. Funke, G., A. von Graevenitz, J. E. Clarridge III, and K. A. Bernard. 1997. Clinical microbiology of coryneform bacteria. Clin. Microbiol. Rev. 10:125159.

9. Holdeman, L. V., E. P. Cato, and W. E. C. Moore (ed.). 1977. Anaerobe laboratory manual, 4th ed. Department of Anaerobic Microbiology, Virginia Polytechnic Institute and State University, Blacksburg.

10. Hollis, D. G., and R. E. Weaver. 1981. Gram-positive organisms: a guide to identification. Special Bacteriology Section, Centers for Disease Control, Atlanta, Ga.

11. Hutson, R. A., D. E. Thompson, and M. D. Collins. 1993. Genetic interrelationships of saccharolytic Clostridium botulinum types B, E and F and related clostridia as revealed by small-subunit rRNA gene sequences. FEMS Microbiol. Lett. 108:103-110.

12. Johnson, J. L., L. V. H. Moore, B. Kaneko, and W. E. C. Moore. 1990. Actinomyces georgiae sp. nov., Actinomyces gerencseriae sp. nov., designation of two genospecies of Actinomyces naeslundii, and inclusion of $A$. naeslundii serotypes II and III and Actinomyces viscosus serotype II in A. naeslundii genospecies 2. Int. J. Syst. Bacteriol. 40:273-286.

13. Lindquist, D., and J. Wong. 1993. Actinomyces pyogenes-like bacteria. J. Clin. Microbiol. 31:3353-3354. (Letter to the editor.)

14. Pascual Ramos, C., G. Foster, and M. D. Collins. 1997. Phylogenetic analysis of the genus Actinomyces based on 16S rRNA gene sequences: description of Arcanobacterium phocae sp. nov., Arcanobacterium bernardiae comb. nov., and Arcanobacterium pyogenes comb. nov. Int. J. Syst. Bacteriol. 47:46-53.

15. Pot, B., P. Vandamme, and K. Kersters. 1994. Analysis of electrophoretic whole-organism protein fingerprints, p. 493-521. In M. Goodfellow and A. G. O'Donnell (ed.), Modern microbial methods. Chemical methods in prokaryotic systematics. J. Wiley and Sons Ltd., Chichester, United King dom.

16. Saitou, N., and M. Nei. 1987. The neighbor-joining method: a new method for reconstructing phylogenetic trees. Mol. Biol. Evol. 4:406-425.

17. Schaal, K. P. 1986. Genus Actinomyces, p. 1383-1418. In P. H. A. Sneath, N. S. Mair, M. E. Sharpe, and J. G. Holt (ed.), Bergey's manual of systematic bacteriology, vol. 2. The Williams \& Wilkins Co., Baltimore, Md.

18. Schleifer, K. H., and O. Kandler. 1972. Peptidoglycan types of bacterial cell walls and their taxonomic implications. Bacteriol. Rev. 36:407-477.

19. Stackebrandt, E., and B. M. Goebel. 1994. Taxonomic note: a place for DNA-DNA reassociation and 16S rRNA sequence analysis in the present species definition in bacteriology. Int. J. Syst. Bacteriol. 44:846-849.

20. von Graevenitz, A., and G. Funke. 1996. An identification scheme for rapidly and aerobically growing gram-positive rods. Zentralbl. Bakteriol. Parasitenkd. Infektionskr. Hyg. Abt. 1 Orig. 284:246-254.

21. von Graevenitz, A., G. Osterhaut, and J. Dick. 1991. Grouping of some clinically relevant gram-positive rods by automated fatty acid analysis. APMIS 99:147-154.

21a.Weiss, N. Unpublished data.

22. Wüst, J., G. Martinetti Lucchini, J. Lüthy-Hottenstein, F. Brun, and M. Altwegg. 1993. Isolation of gram-positive rods that resemble but are clearly distinct from Actinomyces pyogenes from mixed wound infections. J. Clin Microbiol. 31:1127-1135.

23. Wüst, J., S. Stubbs, N. Weiss, G. Funke, and M. D. Collins. 1995. Assignment of Actinomyces pyogenes-like (CDC coryneform group E) bacteria to the genus Actinomyces as Actinomyces radingae sp. nov. and Actinomyces turicensis sp. nov. Lett. Appl. Microbiol. 20:76-81. 